\title{
Application of root cause analysis in improvement of product quality and productivity
}

\author{
Dalgobind Mahto; Anjani Kumar \\ National Institute of Technology (INDIA) \\ mabto123@,rediffmail.com; anj kumar2001@,yahoo.co.in
}

Received July 2008

Accepted December 2008

\begin{abstract}
Root-cause identification for quality and productivity related problems are key issues for manufacturing processes. It has been a very challenging engineering problem particularly in a multistage manufacturing, where maximum number of processes and activities are performed. However, it may also be implemented with ease in each and every individual set up and activities in any manufacturing process. In this paper, root-cause identification methodology has been adopted to eliminate the dimensional defects in cutting operation in $\mathrm{CNC}$ oxy flame cutting machine and a rejection has been reduced from $11.87 \%$ to $1.92 \%$ on an average. A detailed experimental study has illustrated the effectiveness of the proposed methodology.
\end{abstract}

Keywords: root cause analysis, cause and effect diagram, interrelationship diagram and current reality tree

\section{Introduction}

In Root Cause Analysis (RCA) is the process of identifying causal factors using a structured approach with techniques designed to provide a focus for identifying and resolving problems. Tools that assist groups or individuals in identifying the root causes of problems are known as root cause analysis tools. Every equipment failure happens for a number of reasons. There is a definite progression of actions and consequences that lead to a failure. Root Cause Analysis is a step-by-step method 
that leads to the discovery of faults or root cause. An RCA investigation traces the cause and effect trail from the end failure back to the root cause. It is much like a detective solving a crime.

To meet up the high changing market demands along with high quality at comparable prices, one shall have to identify quickly the root causes of quality related problems by reviewing an event, with the goals of determining what has happened, why it has happened and what can be done to reduce the likelihood of recurrence.

\section{Objective and outline of the study}

There are varieties of problems related to product quality and productivity in industries due to varying degrees of abnormality and inefficiency which ultimately causes rejection. Root-cause identification for quality-related problems is a key and necessary step in the operations of manufacturing processes, especially in highthroughput automated processes.

This is predominantly true for the multistage manufacturing processes, which is defined as a process that produces the products under multiple setups. The quality information flow of the product in a multistage manufacturing system and the interaction between the process faults and the product quality characteristics are very complicated. In multistage process, the identification of process root cause is also not simple. It has been observed that the implementation of Root Cause Analysis in a particular single individual setup has simplified the problem.

A case study was done for an industry which was in doldrums condition. The abrupt shutdowns and breakdowns (5.19\% of annual sales), frequent customer complaints (367pa), line balancing delay (27\%), material scarcity or unavailability of matching material (58 days pa), rejection (3.03\% of sales) and various other key success factors were not up to the mark. Therefore, the Root Cause Analysis was undertaken to improve the plant situation. But, the study was confined to the CNC Oxy Flame Cutting Machine. In this paper, the identification of the problem has been simplified taking into consideration a particular stage of manufacturing. It has been observed that RCA can also be implemented in each and every individual set up of manufacturing to improve product quality and productivity. 


\section{Literature review}

Wilson et al. (1993) have defined the Root Cause Analysis as an analytic tool that can be used to perform a comprehensive, system-based review of critical incidents. It includes the identification of the root and contributory factors, determination of risk reduction strategies, and development of action plans along with measurement strategies to evaluate the effectiveness of the plans.

Canadian Root Cause Analysis Framework (2005) says that root cause analysis is an important component of a thorough understanding of "what happened". The team begins by reviewing an "initial understanding" of the event and identifying unanswered questions and information gaps. The information-gathering process includes interviews with staff, who were directly and indirectly involved, examination of the physical environment where the event and other relevant processes took place, and observation of usual work processes. This information is synthesized into a "final understanding", which is then used by the team to begin the "why" portion of the analysis.

Similarly, to solve a problem, one must first recognize and understand what is causing the problem. This is the essence of root cause analysis. According to Wilson et al. (1993) a root cause is the most basic reason for an undesirable condition or problem. If the real cause of the problem is not identified, then one is merely addressing the symptoms and the problem will continue to exist.

Dew (1991) and Sproull (2001) state that identifying and eliminating root causes of any problem is of utmost importance. Root cause analysis is the process of identifying causal factors using a structured approach with techniques designed to provide a focus for identifying and resolving problems. Tools that assist groups and individuals in identifying the root causes of problems are known as root cause analysis tools.

According to Duggett (2004) several root cause analysis tools have emerged from the literature as generic standards for identifying root causes. Some of them are the Why Why Analysis, Multi Vari Analysis, Cause-and-Effect Diagram (CED), the Interrelationship Diagram (ID), and the Current Reality Tree (CRT). He has added that Why Why analysis is the most simplistic root cause analysis tool where as current reality tree is used for possible failures of a system and it is commonly 
used in the design stages of a project and works well to identify causal relationships. There is no shortage of information available about these tools.

The literatures confirmed that these tools do, in fact, have the capacity to find the root causes with varying degrees of accuracy, efficiency, and quality. DOE Guideline Root Cause Analysis Guidance Document February (1992) says that immediately after the occurrence identification, it is important to begin the data collection phase of the root cause process using these tools to ensure that data are not lost. The data should be collected even during an occurrence without compromising with safety or recovery. The information that should be collected consists of conditions before, during, and after the occurrence; personnel involvement (including actions taken); environmental factors; and other information having relevance to the condition or problem. For serious cases, photographing the area of the occurrence from several views may be useful in analysis. Every effort should be made to preserve physical evidence such as failed components, ruptured gaskets, burned leads, blown fuses, spilled fluids, and partially completed work orders and procedures. This should be done despite operational pressures to restore equipment to service. Occurrence participants and other knowledgeable individuals should be identified.

Anderson and Fagerhaug (2000) have simplified the root cause analysis. They provide a comprehensive study about the theory and application of metrics in root cause analysis. It emphasizes the difficulty in achieving process capability in software domain and is cautious about SPC implementation. They mention that the use of control charts can be helpful for an organization especially as a supplementary tool to quality engineering models such as defect models and reliability models. However, it is not possible to provide control as in manufacturing since the parameters being charted are usually in-process measures instead of representing the final product quality. The final product quality can only be measured at the end of a project as opposed to the production in manufacturing industry, so that on-time control on processes becomes impossible. They also underline the necessity of maturity for achieving process stability in development of product quality and productivity. Finally, they bring a relaxed understanding by stating that the processes can be regarded in control when the project meets inprocess targets and achieves end-product quality and productivity improvement goals. 
Arcaro (1997) has presented various tools for identifying root causes. He describes that RCA techniques are constrained within domain and give a detailed tutorial by supporting theoretical knowledge with practical experiences. He states that all RCA techniques may not be applicable for all processes.

Brown (1994) has used the root cause technique to analyze the assembly of commercial aircraft. He has concluded that it is the most effective tool to eliminate the causes in most vital assemblies like aircraft, where utmost safety and reliability is needed.

Brassard (1996), and Brassard and Ritter (1994) have put their emphasis on continuous improvement and effective planning. They have pointed out that Root Cause analyzing tools give management to think ahead about failures and plan accordingly. They emphasize that process improvement models implicitly direct companies to implement RCA as a crucial step for project level process control and organizational level process improvement purposes. Quantitative Process Management requires establishing goals for the performance of the project's defined process, taking measurements of the process performance, analyzing these measurements, and making adjustments to maintain process performance within acceptable limits.

Cox and Spencer (1998) have advocated that RCA tools effectively give solution to handle constraints and arrive at an appropriate decision. Like Cox and Spencer (1998), Dettmer (1997) has also used root cause analysis on management of constraints. He presents one of the earliest studies on the debate of applying Root Cause Analysis to processes. A proper management decision is necessary to succeed the RCA tools and methods in a particular environment.

Lepore and Cohen (1999), Moran et al. (1990), Robson (1993) and Scheinkopf (1999) move ahead that when change is needed, then think root cause analyzing, identifying and eliminating. The foundations of their studies are pioneering one as they question an accepted practice for root cause analysis and the results of the example studies are encouraging. However, the studies are far from being practical one as they include too many parameters and assumptions.

Smith (2000) has explained that Root Cause Tools can resolve conflicting strategies, policies, and measures. The perception is that one tool is as good as another tool. While the literature was quite complete on each tool as a stand-alone 
application and their relationship with other problem solving methods. There are very few literatures available on the comparative study of various root cause analysis tools and methods. The study on three tools namely Cause-and-Effect Diagram (CED), the Interrelationship Diagram (ID), and the Current Reality Tree (CRT) is deficient on how these three tools directly compare to each other. In fact, there are only two studies that compared them and the comparisons were qualitative.

Likewise, Fredendall et al. (2002) have also compared the CED and the CRT using previously published examples of their separate effectiveness. While Pasquarella et al. (1997) compared CED, ID and CRT on Equipment/Material Problem, Procedure Problem, Personnel Error, Design Problem, Training Deficiency, Management Problem and External Phenomena using a one-group post-test design with qualitative responses.

There is little published research that quantitatively measures and compares the Why Why Analysis, Multi Vari Analysis, Cause-and-Effect Diagram (CED), the Interrelationship Diagram (ID), and the Current Reality Tree (CRT).

Geno (2007) has presented some insight into the comparison of common root cause analysis tools and methods. He indicates that there are some comparative differences between tool and method of a RCA. He has added that tools are included along with methods because tools are often touted and used as a fullblown root cause analysis.

\section{Basic terminologies in root cause analysis}

- Facility: Facility may be defined as any equipment, structure, system, process, or activity that fulfills a specific purpose. Some of the examples include production or processing plants, accelerators, storage areas, fusion research devices, nuclear reactors, coal conversion plants, magneto hydrodynamics experiments, windmills, radioactive waste, disposal systems, testing and research laboratories, transportation activities, and accommodations for analytical examinations of irradiated and unpredicted components.

- Condition: It may be defined as a state, whether or not resulting from an event, that may have adverse safety, health, quality assurance, security, 
operational, or environmental implications. A rendition is usually programmatic in nature; for example, an (existing) error in analysis or calculation, an anomaly associated with (resulting from) design or performance, or an item indicating weaknesses in the management process are all conditions.

- Root Cause: The cause that, if corrected, would prevent recurrence of this and similar occurrences. The root cause does not apply to this occurrence only, but has generic implications to a broad group of possible occurrences, and it is the most fundamental aspect of the cause that can logically be identified and corrected. There may be a series of causes that can be identified, one leading to another. This series should be pursued until the fundamental, correctable cause has been identified. For example, in the case of a leak, the root cause could be management, not its maintenance, which ensures that it is effectively managed and controlled. This cause could have led to the use of improper seal material or missed preventive maintenance on a component, which ultimately led to the leak. In the case of a system misalignment, the root cause could be a problem in the training program, leading to a situation in which operators are not fully familiar with control room procedures and are willing to accept excessive distractions.

- Causal Factor: A condition or an event that results in an effect (anything that shapes or influences the outcome). This may be anything from noise in an instrument channel, a pipe break, an operator error, or a weakness or deficiency in management or administration. In the context of DOE there are seven major causal factor categories. These major categories are:

o Equipment/Material Problem

o Procedure Problem

o Personnel Error

o Design Problem

o Training Deficiency

o Management Problem 


\section{Root cause analysis tools and techniques}

Many Root Cause Analysis Tools have emerged from the literature as generic standards for identifying root causes. They are the Cause-and-Effect Diagram (CED), the Interrelationship Diagram (ID), and the Current Reality Tree (CRT), Why Why Analysis, Multi Vari Analysis. Ample of information is available about these tools, in open literature (See References).

\subsection{Causes-and-effect diagram (CED)}

This diagram, also called Ishikawa or Fishbone Diagram, is used to associate multiple possible causes with a single effect. The diagram is constructed to identify and organize the possible causes for a particular single effect. Causes in Cause and Effect Diagram are frequently arranged in four major categories. For manufacturing cases it is Manpower, Methods, Materials and Machinery. For Administration and service sectors, it is Equipment, Policies, Procedures and People. Ishikawa advocated the CED as a tool for breaking down potential causes into more detailed categories so that they can be organized and related into factors which help in identifying the root cause.

\subsection{Interrelationship diagram (ID)}

Mizuno supported the ID as a tool to quantify the relationships between factors and thereby classify potential causal issues or drivers. The interrelationships among the operations are shown as 'in and out' in each stages of operation. The weight factors, which may include causes, effects, or both, of in and out are determined on the basis on logical sequence.

\subsection{Current reality tree (CRT)}

Current Reality Tree is a tool to find logical interdependent chains of relationships between undesirable effects leading to the identification of the core cause. It depicts the real status under prevailing current conditions with regard to causality, factor relationships, usability, and participation. 


\subsection{Why why analysis}

An important component of root cause analysis is a thorough understanding of "what happened". The team begins by reviewing an "initial understanding" of the event and identifying unanswered questions and information gaps. The information-gathering process includes interviews with staffs and workers who were directly and indirectly involved with the physical environment where the event and other relevant processes took place, along with observation of usual work processes. This information is synthesized into a "final understanding", which is further used by the team to begin the "why" portion of the analysis in a logical sequence to find a logical solution to the problem.

It is one of the many brainstorming methodology of asking "why" five times repeatedly to help in identifying the root cause of a problem. If a problem is repeatedly questioned, each time an alternative solution comes out which is linked to the root cause. However, asking why may be continued till getting an agreeable solution. Five is an arbitrary figure. The theory is that after asking "why" five times one is likely to arrive at the root cause.

\subsection{Multi vari analysis}

It is the tool of finding root causes and its relationship with Cyclic Error, Temporal Error and Positional Error. Its aim is to find out whether a cause is repeatable in nature or not. If it is repeated, it has reoccurred at the certain intervals or not. The causes have re-occurred or not in a particular position. In fact the basic intent of this tool is to find out why this variation has taken place from the specified specifications. The main objective of a Multi Vari Analysis is to reduce a large number of unknowns and unmanageable causes of variation to a much smaller family of related variables containing the dominant cause. The basic data required for Multi Vari Analysis are the following:

- Number of day's sample data is taken

- Number of shifts per day

- Number of hours in a shift that sample data is taken

- Number of units in an hour that sample data is taken from 
- Factors, which may include causes, effects, or both and their levels

\section{Root cause analysis methods}

There are many of these methods, which are specialized and apply to specific situations or objectives (readers can find many examples in the references). Most have their own cause categorizations, but all are very effective when used within the scope for which they have been designed. The most common methods are (DOE Guideline, 1992).

\subsection{Events and causal factor analysis}

Events and Causal Factor Analysis is a method in which personnel conduct a stepby-step reenactment of their actions for the observer without carrying out the actual function. If appropriate, it may be possible to use a simulator for performing the walk-through rather than the actual work location. Its objectives include:

- Determining how a task was really performed

- Identifying problems in human-factors design, discrepancies in procedural steps, training etc.

- Preconditions are that participants must be the people who actually do the task.

Steps in Cause and Effects Task Analysis are as follows:

- Obtain preliminary information so that one may know that what the person was doing when the problem or inappropriate action occurred.

- Decide on a task of interest.

- Obtain necessary background information.

- Obtain relevant procedures

- Obtain system drawings, block diagrams, piping and instrumentation diagrams, etc. 
- Interview personnel who have performed the task to have an understanding of how the task should be performed.

Produce a guiding outline as to how the task will be carried out. A procedure with underlined key items is the easiest way of doing this. It should indicate the steps in performing task, key controls and displays so that:

- One will know what to look for

- One will be able to record actions more easily.

- Thoroughly familiarize oneself with the guide and decide exactly what information are going to be recorded and how it will be recorded.

- One may like to check off each steps and controls or displays used as they occur. Discrepancies and problems may be noted in the margin or in a space provided for comments, adjacent to the steps.

- Select personnel who normally perform the task. If the task is performed by a crew, crew members should play the same role as they fulfill when carrying out the task.

- Observe personnel walking through the task and record their actions and use of displays and controls. Note down the discrepancies and problem areas.

\subsection{Change Analysis}

Change Analysis looks at a problem by analyzing the deviation between what is expected and what actually has happened. The evaluator essentially asks about the difference that has occurred to make the outcome of the task or activity as compared to that of all the other times this task or activity was successfully completed. This technique consists of asking the questions: What? When? Where? Who? How? Answering these questions should provide direction toward answering the root cause determination question: Why? Primary and secondary questions included within each category will provide the prompting necessary to thoroughly answer the overall question. Some of the questions will not be applicable to any given condition. Some amount of redundancy exists in the questions to ensure that all items are addressed. Several key elements include the following: 
- Consider the event containing the undesirable consequences. Consider a comparable activity that did not have the undesirable consequences. Compare the condition containing the undesirable consequences with the reference activity.

- Set down all known differences whether they appear to be relevant or not.

- Analyze the differences for their effects in producing the undesirable consequences. This must be done in detail with careful attention, ensuring that obscure and indirect relationships are identified (e.g., a change in color or finish may change the heat transfer parameters and consequently affect system temperature).

- Integrate information into the investigative process relevant to the causes of, or the contributors to, the undesirable consequences.

Change Analysis is a good technique to use whenever the causes of the condition are obscure, one does not know where to start, or suspect a change that may have contributed to the condition. Not recognizing the compounding of change (e.g., a change made five years previously combined with a change made recently) is a potential shortcoming of Change Analysis. Not recognizing the introduction of gradual change as compared with immediate change is also possible.

This technique may be adequate to determine the root cause of a relatively simple condition. In general, though it is not thorough enough to determine all the causes of more complex conditions, the following questions "WHAT?" help in identifying information required on the worksheet.

- What is the condition?

- What occurred to create the condition?

- What occurred prior to the condition?

- What occurred following the condition?

- What activity was in progress when the condition occurred?

- What activity was in progress when the condition was identified? 


\subsection{Barrier analysis}

There are many things that should be addressed during the performance of a Barrier Analysis. The questions listed below are designed to aid in determining what barrier failed, thus resulting in the occurrence. What barriers existed between the second, third, etc. condition or situation?

- If there were barriers, did they perform their functions? Why?

- Did the presence of any barriers mitigate or increase the occurrence severity? Why?

- Were any barriers not functioning as designed? Why?

- Was the barrier design adequate? Why?

- Were there any barriers in the condition/situation source(s)? Did they fail? Why?

- Were there any barriers on the affected component(s)? Did they fail? Why?

- Were the barriers adequately maintained?

- Were the barriers inspected prior to expected use?

- Why were any unwanted energies present?

- Is the affected system/component designed to withstand the condition/situation without the barriers? Why?

- What design changes could have prevented the unwanted flow of energy? Why?

- What operating changes could have prevented the unwanted flow of energy? Why?

- What maintenance changes could have prevented the unwanted flow of energy? Why?

- Could the unwanted energy have been deflected or evaded? Why? 
- What other controls are the barriers subject to? Why?

- Was this event foreseen by the designers, operators, maintainers, anyone?

- Is it possible to have foreseen the occurrence? Why?

- Is it practical to have taken further steps to have reduced the risk of the occurrence?

- Can this reasoning be extended to other similar systems/components?

- Were adequate human factors considered in the design of the equipment?

- What additional human factors could be added? Should be added?

- Is the system/component user friendly?

- Is the system/component adequately labeled for ease of operation?

- Is there sufficient technical information for operating the component properly? How do you know?

- Is there sufficient technical information for maintaining the component properly? How do you know?

- Did the environment mitigate or increase the severity of the occurrence? Why?

- What changes were made to the system/component immediately after the occurrence?

- What changes are planned to be made? What might be made?

- Have these changes been properly, adequately analyzed for effect?

- What related changes to operations and maintenance have to be made now?

- Are expected changes cost effective? Why? How do you know? 
- What would you have done differently to have prevented the occurrence, disregarding all economic considerations (as regards operation, maintenance, and design)?

- What would you have done differently to have prevented the occurrence, considering all economic concerns (as regards operation, maintenance and design)?

\subsection{Management oversight and risk tree (MORT) analysis}

It is the methodology adopted by the root cause analysis team with the active support of management. To perform the MORT analysis:

- Identify the problem associated with the occurrence and list it as the top event.

- Identify the elements on the "what" side of the tree that describe what happened in the occurrence.

- For each barrier or control problem, identify the management elements on the "why" side of the tree that permitted the barrier control problem.

- Describe each of the identified inadequate elements or problems and summarize your findings.

A brief explanation of the "what" and "why" may assist in using mini-MORT for causal analyses.

- Barriers that surround the hazard and/or the target and prevent contact or controls and procedures that ensure separation of the hazard from the target

- Plans and procedures that avoid conflicting conditions and prevent programmatic impacts.

- In a facility, what functions implement and maintain these barriers, controls, plans, and procedures? 
- Identifying the hazards, targets, and potential contacts or interactions and specifying the barriers/controls that minimize the likelihood and consequences of these contacts

- Identifying potential conflicts/problems in areas such as operations, scheduling, or quality and specifying management policy, plans, and programs that minimize the likelihood and consequences of these adverse occurrences

- Providing the physical barriers: designing, installation, signs/warnings, training or procedures

- Providing planning/scheduling, administrative controls, resources, or constraints. Verifying that the barriers/controls have been implemented and are being maintained by operational readiness, inspections, audits, maintenance, and configuration/change control

- Verifying that planning, scheduling, and administrative controls have been implemented and are adequate

- Policy and policy implementation (identification of requirements, assignment of responsibility, allocation of responsibility, accountability, vigor and example in leadership and planning).

\subsection{Human performance evaluation}

Human Performance Evaluation is used to identify factors that influence task performance. It is most frequently used for man-machine interface studies. Its focus is on operability and work environment, rather than training operators to compensate for bad conditions. Also, human performance evaluation may be used for most occurrences since many conditions and situations leading to an occurrence ultimately result from some task performance problem such as planning, scheduling, task assignment analysis, maintenance, and inspections. Training in ergonomics and human factors is needed to perform adequate human performance evaluations, especially in man-machine interface situations. 


\subsection{Kepner-Tregoe problem solving and decision making}

Kepner-Tregoe is used when a comprehensive analysis is needed for all phases of the occurrence investigation process. Its strength lies in providing an efficient, systematic framework for gathering, organizing and evaluating information and consists of four basic steps:

- Situation appraisal to identify concerns, set priorities, and plan the next steps.

- Problem analysis to precisely describe the problem, identify and evaluate the causes and confirm the true cause. (This step is similar to change analysis).

- Decision analysis to clarify purpose, evaluate alternatives, and assess the risks of each option and to make a final decision.

- Potential problem analysis to identify safety degradation that might be introduced by the corrective action, identify the likely causes of those problems, take preventive action and plan contingent action. This final step provides assurance that the safety of no other system is degraded by changes introduced by proposed corrective actions.

These four steps cover all phases of the occurrence investigation process and thus, Kepner-Tregoe can be used for more than causal factor analysis. This systems approach prevents overlooking any aspect of the concern.

\section{Difference between RCA tools and techniques and RCA methods}

To differentiate Root Cause Analysis Tools and Root Cause Analysis Methods, a standard is needed to which they could be compared. It is generally agreed that the purpose of root cause analysis is to find effective solutions to our problems such that they do not recur. Accordingly, an effective root cause analysis process should provide a clear understanding of exactly how the proposed solutions meet this goal.

To provide this assurance an effective process should meet the following six criteria

- Clearly defines the problem and its significance to the problem owners. 
- Clearly delineates the known casual relationships that combined to cause the problem.

- Clearly establishes causal relationships between the root causes and the defined problem

- Clearly presents the evidence used to support the existence of identified causes.

- Clearly explains how the solutions will prevent recurrence of the defined problem.

- Clearly documents criteria 1 through 5 in final RCA report so others can easily follow the logic of the analysis

Therefore, there is a clear distinction between an RCA Tool and RCA Method. A tool is distinguished by its limited use pertaining to particular phenomena or situation, while a method may involve many steps and processes and has wide usage with the flexibility to modify to some extent pertaining to particular phenomena or situation. Comparative differences of selected RCA Tools and RCA Methods have been shown in the Table 1.

\begin{tabular}{|l|c|c|c|c|c|c|c|}
\hline \multicolumn{1}{|c|}{ Tool / Method } & Type & $\begin{array}{c}\text { Defines } \\
\text { Problem }\end{array}$ & $\begin{array}{c}\text { Defines } \\
\text { all causal } \\
\text { relation- } \\
\text { ships }\end{array}$ & $\begin{array}{c}\text { Provides } \\
\text { a causal } \\
\text { path to } \\
\text { root } \\
\text { causes }\end{array}$ & $\begin{array}{c}\text { Explains } \\
\text { how } \\
\text { Delineates } \\
\text { evidence } \\
\text { solutions } \\
\text { prevent } \\
\text { recurrence }\end{array}$ & $\begin{array}{c}\text { Easy to } \\
\text { follow } \\
\text { report }\end{array}$ \\
\hline $\begin{array}{l}\text { Causes-and-Effect } \\
\text { Diagram }\end{array}$ & Tool & Yes & Limited & No & No & No & No \\
\hline $\begin{array}{l}\text { Interrelationship } \\
\text { Diagram }\end{array}$ & Tool & Yes & No & No & No & No & No \\
\hline $\begin{array}{l}\text { Current Reality } \\
\text { Tree }\end{array}$ & Tool & Yes & No & Limited & No & Limited & No \\
\hline Why Why Analysis & Tool & Yes & No & Yes & No & No & No \\
\hline Multi Vari Analysis & Tool & Limited & Limited & Yes & No & No & Yes \\
\hline $\begin{array}{l}\text { Events and Causal } \\
\text { Factor Analysis }\end{array}$ & Method & Yes & Limited & No & No & No & No \\
\hline $\begin{array}{l}\text { Change Analysis } \\
\text { Barrier Analysis }\end{array}$ & Method & Yes & No & No & No & No & No \\
\hline $\begin{array}{l}\text { Management } \\
\text { Oversight and Risk } \\
\text { Tree Analysis }\end{array}$ & Method & Yes & No & No & No & No & No \\
\hline $\begin{array}{l}\text { Human } \\
\text { Performance } \\
\text { Evaluation }\end{array}$ & Method & Yes & Yes & Yes & No & Limited & Yes \\
\hline $\begin{array}{l}\text { Kepner - Tregoe } \\
\text { Problem Solving } \\
\text { and Decision } \\
\text { Making }\end{array}$ & Method & Yes & Yes & Yes & No & Limited & Yes \\
\hline
\end{tabular}

Table 1. "Comparison of selected RCA tools and RCA methods". 


\section{Root cause analysis (RCA) process}

The RCA method brings a team of, usually 3 to 6 or as demanded, knowledgeable people together to investigate the failure using evidence left behind from the fault. The team brainstorms to find as many causes of the fault as possible. By using what evidence remained after the fault and through discussions with people involved in the incident, all the non-contributing causes are removed and the contributing causes retained.

A fault tree is constructed starting with the final failure and progressively tracing each cause that led to the previous cause. This continues till the trail can be traced back no further. Each result of a cause must clearly flow from its predecessor (the one before it). If it is clear that a step is missing between causes it is added in and evidence looked for to support its presence. Once the fault tree is completed and checked for logical flow, the team then determines what changes has to be made to prevent the sequence of causes and consequences from again occurring.

Root cause analysis is defined in the Canadian Root Cause Analysis Framework1 as "an analytic tool that can be used to perform a comprehensive, system-based review of critical incidents. It includes the identification of the root and contributory factors, determination of risk reduction strategies, and development of action plans along with measurement strategies to evaluate the effectiveness of the plans."

Root cause analysis in industries is best conducted by a multidisciplinary team, involving individuals knowledgeable about Productivity, as well as knowledgeable in the Quality area of focus. Information is gathered through interviews with staff members who were directly and indirectly involved, as well as family members when possible. In addition, the team reviews the location where the incident occurred, examines the products, devices, environment and work processes involved, and reviews relevant documentation and literature.

To improve product quality and productivity, the analysis team proceeds through a series of probing questions focused on answering "why" and "caused by" questions to delineate the various factors that contributed to the event and which, if left unmitigated, could contribute to another event. The focus is on systems and processes and their interaction with individuals, with the understanding that the individuals involved did not intentionally act to cause harm, and given the same set of circumstances, the outcome would be the same for any individuals involved. The 
root cause analysis process encourages high-leverage system changes that, if implemented, will have lasting effects on product quality and productivity with safety.

Relevant literature and practice standards are considered in formulating recommendations and actions. To make it understand the significance of such a system enhancement, it has been provided an analogous example from the automotive industry considering the steps for successful root cause analysis as given below.

\subsection{Steps for successful root cause analysis (RCA)}

Root Cause Analysis (RCA) is a useful tool for trouble shooting breakdowns and efficiently coming to a solution. For successful implementation of RCA following seven steps are necessary and once completed that will naturally result in elimination of root causes and will increase profits.

\section{Seven points of RCA are...}

- Describe the actual Cause.

- Define the physical phenomena of the Cause

- Organize the details of the Cause by using the '3W2H' (with what, when, where, how, how much) tool.

- Work as a team, respecting each other's expertise and knowledge, rather than individually.

- Consider every possible cause of the Cause.

- Verify all logical causes and eliminate all illogical causes.

- If determined that the cause among the causes was human error, separate that cause from the physical causes.

\section{Outline of the empirical case study}

The experimentation was carried out at one of the automotive component manufacturing plants situated in Jamshedpur, India. The plant has sophisticated 
modern machine tools. This plant is professionally managed and it has got ISO 9002 and ISO 14001-system certification. It has also implemented Total Quality Management. The departments have been computerized and linked through Local Area Networking (LAN) to enhance accessibility. Maintenance management systems are in practice. It is also backed up by an advanced computer aided condition monitoring system. The plant processes may be roughly categorized into the following blocks (as per the material flow):

- Raw Material Processes

- Intermediate Processes

- Final Processes

The products manufactured by the plant comprise of different components, used in construction equipments and in conveying systems. To improve the product quality and productivity Oxy Flame cutting machine was chosen. This machine is composed of electrical and mechanical systems. The machine moves along $X$ axis through L.T. Mechanism (Long Travel Mechanism) and through cross travel i.e. along $Y$ axis travel is done in cross travel Beam by the three cutting torches which are fitted with sensors for which command comes from the CPU fitted with the machine. This machine has three cutting torches by which the materials are being cut by oxy flame. It uses multi channel data format for storage of time data, spectra, etc., including: function identifier, sampling frequency, input/output point and direction, input/output units, free text lines, $\mathrm{X}_{-}, \mathrm{Y}-, \mathrm{Z}$-axis labels, auxiliary custom fields. Extensive commands to extract information from headers including a search function. It uses dissolved Acetylene and Oxygen to generate flame to cut the material in a straight line or in curves. When a single torch is used, it can cut straight beveling. The torches have proximity sensors so that there should be a accurate distance between the Raw material to be cut and Torch tip. The tool holder is that part of the system where the sensor of the cutting edge is placed. When the machine begins cutting, the cutting torches move according to DNC (Direct Numerical Control) programme. This DNC programme is converted from a CNC (Computerized Numerical Control) programme for cutting. A detector is also placed to capture the problems in cutting, which enables an operator to make adjustments of speed, cutting gap or Gas flow. A photograph of the machine is presented in Figure 1. 
Now the seven points as described above has been adopted to study the empirical case.

\subsection{Finding and Defining the Actual Cause (Step 01)}

The problem was encountered in the initial processing of the material. The capacity utilization of the plant was around $55 \%$ to $65 \%$ due to problems in processing of materials itself and there was always fire-fighting for want of material. But, no root causes were identified as to why there was such a problem. This reason was one of the key contributory factors for the lower level of productivity

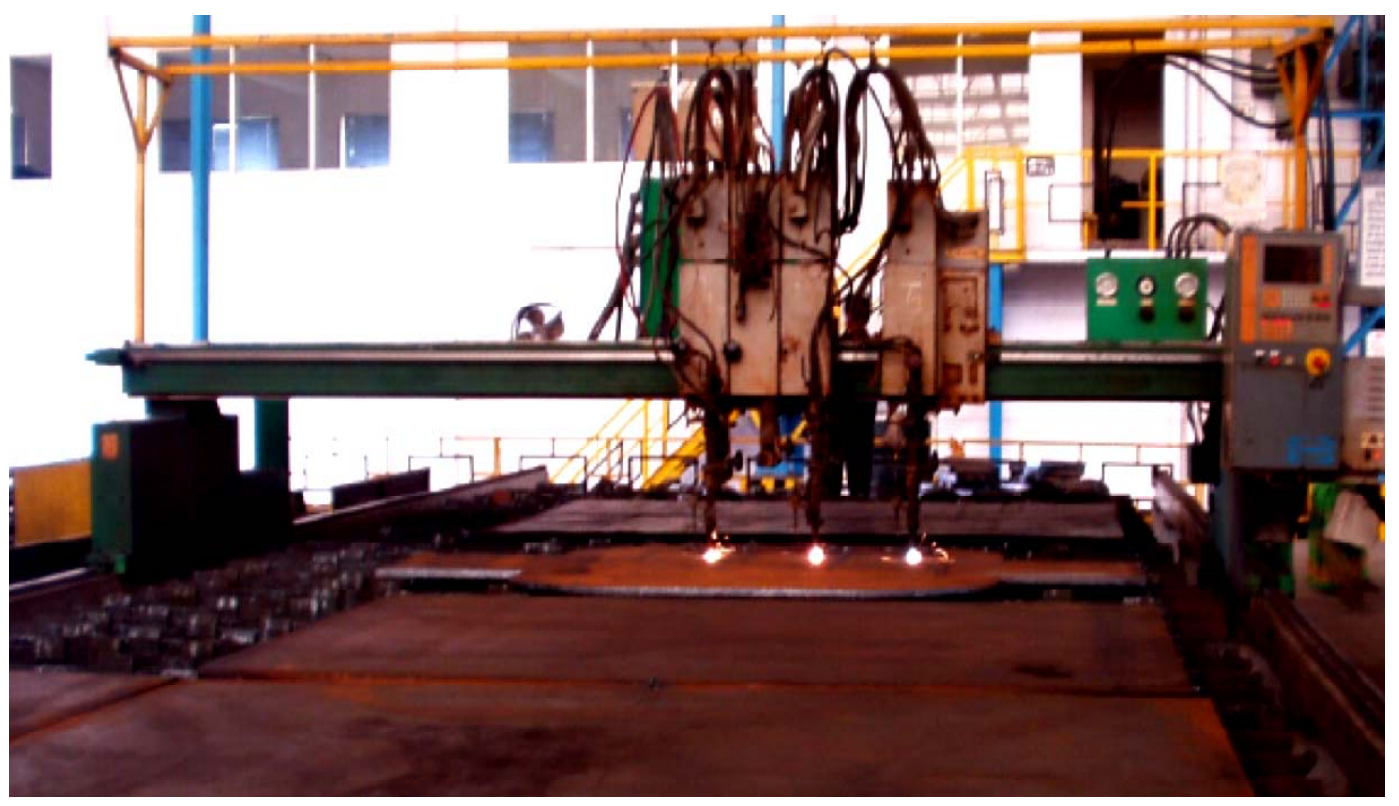

Figure 1. "Sample machine taken for root cause analysis".

\subsection{Physical phenomena of the cause (Step 02)}

The cutting operation was to be performed in all the items but how far it is related to or it was influencing the production processes had never been studied earlier. Therefore, a value stream mapping was done first by selecting a job (Pivot Frame) to understand the percentile impact of gas cutting operation on the production process. The defect on cut material increases the cycle time of each activity and adds more non-value adding times. Hence, to pin point non-value adding activities contributed by gas cutting, data were captured activity wise.

Now, the Value Stream Mapping was done and its detail is tabulated in Table 2. Different operations have been categorized and entered in the table in abbreviated 
terms. The details of the abbreviation used are given below. The same abbreviations shall be used here in after.

- $\quad \mathrm{VA}=$ Value Adding Activities

- $\quad$ NVA $=$ Non Value Adding Activities

- $\quad \mathrm{EOT}=$ Electric Operated Tower Crane

- $\quad$ DNC $=$ Direct Numerical Control system

- $\quad \mathrm{CNC}=$ Computerized Numerical Control system

- $\quad$ DTD $=$ Desk to Desk (Lean tool)

- $\quad \mathrm{SPC}=$ Statistical Process Control

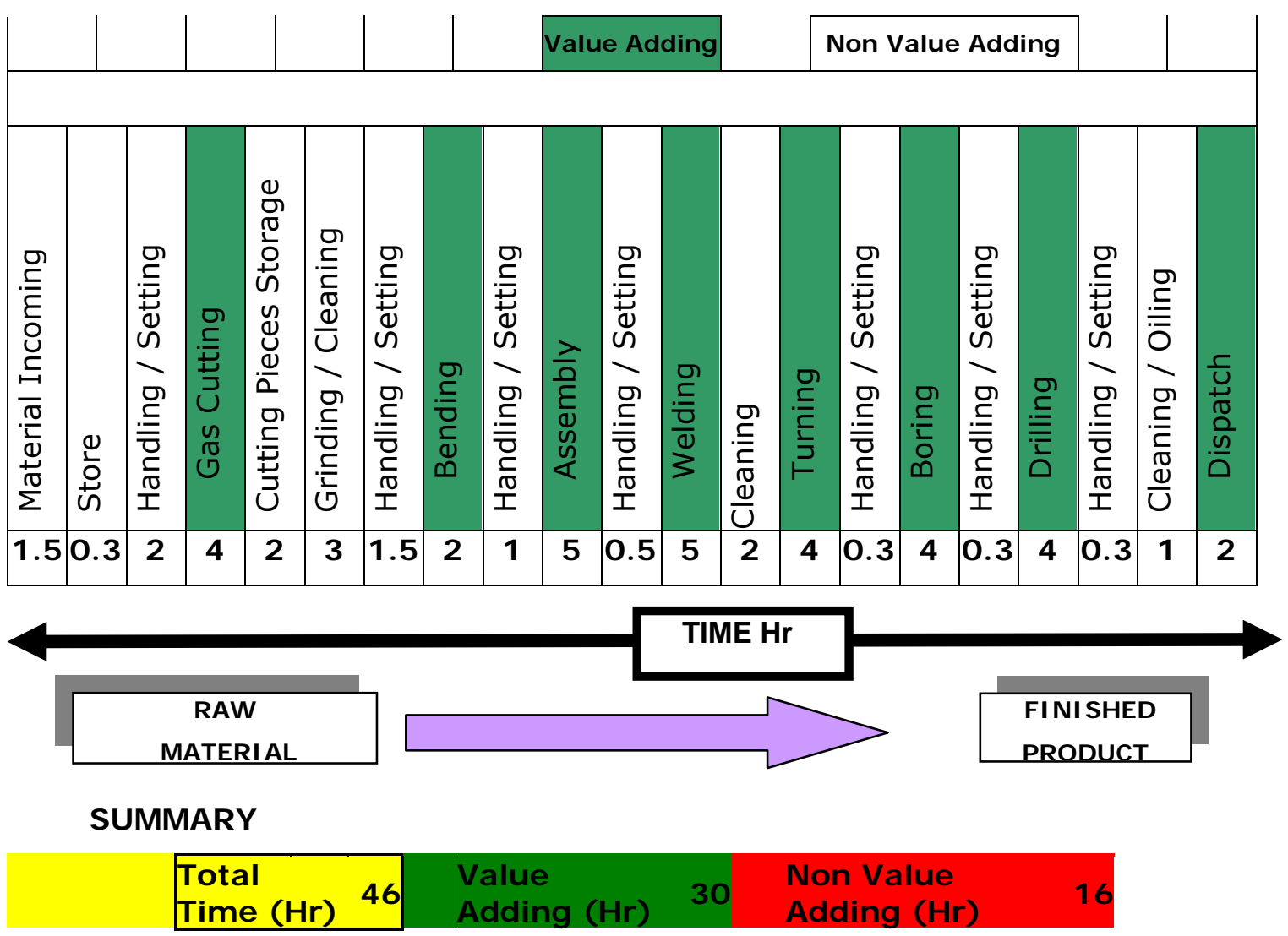

Note: In process Inspection is carried out at every stage

Figure 2. "Value stream mapping before root cause analysis". 
In the above sample study, it was found that the non-value adding activities were higher than the value adding activities. The operations entered in serial numbers 3 to 5,7 to 12,18 to 20,25 and 26 (Table 2) are non-value adding activities associated to gas cutting operation. It comes out to be 07 hours 40 minutes of non-value added activity with total throughput time of 12 Hours 50 minutes.

\begin{tabular}{|c|c|c|c|c|c|}
\hline $\begin{array}{l}\text { SI } \\
\text { No }\end{array}$ & $\begin{array}{l}\text { Operations in } \\
\text { Sequence }\end{array}$ & $\begin{array}{l}\text { Machine wise Activity } \\
\text { Description }\end{array}$ & $\begin{array}{l}\text { Resources } \\
\text { involved }\end{array}$ & $\begin{array}{l}\text { Time } \\
\text { taken } \\
\text { (Min) }\end{array}$ & Category \\
\hline 1 & $\begin{array}{l}\text { Raw Material } \\
\text { handling }\end{array}$ & $\begin{array}{l}\text { Handling from stock yard } \\
\text { to Cortina Machine }\end{array}$ & $\begin{array}{c}\text { EOT Crane, } 1 \\
\text { Operator, } 1 \text { Helper }\end{array}$ & 25 & NVA \\
\hline 2 & Data conversion & $\begin{array}{c}\text { DNC to CNC Cortina } \\
\text { Machine }\end{array}$ & $\begin{array}{c}1 \text { Engineer, } 1 \\
\text { Computer }\end{array}$ & 10 & NVA \\
\hline 3 & CNC Cutting & At Cortina Machine & 1 Operator & 35 & VA \\
\hline 4 & $\begin{array}{l}\text { Material Removal } \\
\text { shifting and } \\
\text { Inspection } \\
\end{array}$ & Cortina Machine & $\begin{array}{l}2 \text { helper, } 1 \text { Crane, } 1 \\
\text { Inspector }\end{array}$ & 55 & NVA \\
\hline 5 & Material Preparation & Manual grinding & $\begin{array}{c}2 \text { Operator, } 2 \\
\text { Grinding machine }\end{array}$ & 25 & NVA \\
\hline 6 & Inspection & Manual grinding & 1 Inspector & 20 & NVA \\
\hline 7 & $\begin{array}{l}\text { Segregation \& } \\
\text { Shifting }\end{array}$ & $\begin{array}{c}\text { Material Preparation, } \\
\text { Bending, Assembly or } \\
\text { Machining }\end{array}$ & $\begin{array}{l}1 \text { Operator, } 1 \\
\text { Helper, fork lifts, } \\
\text { trolleys, Crane }\end{array}$ & 30 & NVA \\
\hline 8 & Assembly & $\begin{array}{l}\text { Collection of prepared } \\
\text { material for assembly }\end{array}$ & $\begin{array}{c}1 \text { Operator, } 2 \\
\text { Helper, Fixtures, } \\
\text { Gauges }\end{array}$ & 40 & VA \\
\hline 9 & Inspection & Assembly & 1 Inspector & 20 & NVA \\
\hline 10 & $\begin{array}{l}\text { Loading \& setting at } \\
\text { Manipulator }\end{array}$ & For welding & $\begin{array}{c}\text { EOT Crane, } 1 \\
\text { Operator }\end{array}$ & 15 & NVA \\
\hline 11 & Welding & Mig welding & $\begin{array}{l}1 \text { Operator, } \mathrm{Co} 2 \\
\text { Gas, Welding } \mathrm{M} / \mathrm{c}\end{array}$ & 60 & VA \\
\hline 12 & Inspection & Manually, UT machine & 1 Inspector & 25 & NVA \\
\hline 13 & $\begin{array}{l}\text { Unloading \& Shifting } \\
\text { to Machining centre }\end{array}$ & Unloading by EOT Crane & 1 Helper, Fork lift & 20 & NVA \\
\hline 14 & Setting at VTL & For machining & $\begin{array}{l}1 \text { Helper, } 1 \text { EOT } \\
\text { Crane, } 1 \text { Operator, }\end{array}$ & 20 & NVA \\
\hline 15 & Base Machining & Fixture and special tool & 1 Operator & 50 & VA \\
\hline 16 & Inspection & Vernier, Jig & 1 Inspector & 20 & NVA \\
\hline 17 & $\begin{array}{c}\text { Unloading \& Shifting } \\
\text { to Boring }\end{array}$ & Fork lift, EOT Crane & $\begin{array}{l}1 \text { Helper, Fork lift, } \\
\text { EOT Crane }\end{array}$ & 20 & NVA \\
\hline 18 & $\begin{array}{c}\text { Setting at Horizontal } \\
\text { Boring }\end{array}$ & For Machining & $\begin{array}{c}1 \text { Helper, EOT } \\
\text { Crane, } 1 \text { Operator, }\end{array}$ & 20 & NVA \\
\hline 19 & Boring & $\varnothing 90 \pm 1 ., \varnothing 80 \pm 1$ & 1 Operator & 50 & VA \\
\hline 20 & Inspection & Vernier, Jig & 1 Inspector & 20 & NVA \\
\hline 21 & $\begin{array}{l}\text { Unloading \& Shifting } \\
\text { to Drilling \& Tapping }\end{array}$ & Fork lift, EOT Crane & 1 Helper, & 20 & NVA \\
\hline 22 & Setting at Radial Drill & Drilling Fixing of Jig & $\begin{array}{c}1 \text { Helper, EOT } \\
\text { Crane, } 1 \text { Operator }\end{array}$ & 20 & NVA \\
\hline 22 & Drilling \& Tapping & $\varnothing 15.5+0.2, \varnothing 20+0.3$ & 1 Operator & 75 & VA \\
\hline 23 & Inspection & Gauge, Tap & 1 Inspector & 25 & NVA \\
\hline 24 & $\begin{array}{c}\text { Unloading \& Shifting } \\
\text { to cleaning }\end{array}$ & Fork lift, EOT Crane & $\begin{array}{c}1 \text { Helper, Fork lift, } \\
\text { EOT Crane }\end{array}$ & 15 & NVA \\
\hline 25 & $\begin{array}{c}\text { Cleaning \& surface } \\
\text { treatment }\end{array}$ & Phosphating and Rustoil & $\begin{array}{c}1 \text { Operator, } 1 \\
\text { helper }\end{array}$ & 25 & NVA \\
\hline 26 & Inspection & Visually & 1 Inspector & 10 & NVA \\
\hline & Total & & & $\sum 770$ & \\
\hline
\end{tabular}

Table 2. "Value stream mapping before root cause analysis". 
We have considered one more items named as Dump Lever for the analysis and value mapping was done (Fig. 2) as it was done earlier so as to know its effect on the production process. It is evident from Fig. 2 that the total throughput time of the product was 46 hours in which 16 hours were non-value adding activities. The non-value adding activities have been coloured "RED" to highlight the activities.

\subsection{Organization of the details of the causes using 3 W2H (Step 03)}

The raw material was processed mainly on CNC Oxy Flame Cutting Machine. The main operations were categorized into different operational blocks like Transmission System, Gas System, Structure and different assemblies, Lubrication, Traverse Carriage System, CNC programming and Cutting Torch Suspension system etc.

The root cause of these items were organized and defined and against each of these blocks the Reliability per day, assuming constant rate of failures, was worked out for several days in \%. It was found that three blocks namely Transmission System, Lubrication, and Cutting Torch Suspension system, were the most unreliable blocks. It was observed that the reliability per day of the entire system was $57 \%$ and the average time between two successive failures was 03 hours 57 minutes. That is, we would expect a failure to happen every 4 hours or so. The average time of repair for the system is 01 hour 28 minutes. That is, each failure one may expect to be rectified within 1 hour 30 minutes.

\subsection{Formation of Team (Step 04)}

Thereafter, a multi-disciplinary Cross Functional Team (CFT) of knowledge workers was formed. Managers and engineers were taken from different departments namely, Mechanical, Electrical, Instrumentation, Production, and Quality departments, since they were related to above case studies.

\subsection{Possible Causes of the Root Cause (Step 05)}

The nature of problem, specific reason and class of the problem occurring at source has been identified, classified as Primary, Secondary and Tertiary and tabulated in Table 3. Primary reasons are those due to which the material is rejected. Secondary reasons are those in which modification can be possible to make it 
usable. The tertiary natures of problem are those, which will be present in the work pieces but undesirable; and it is to be attended before further processing.

The CFT group then had a brain storming session to decide as to how to eliminate the problem. Thereafter, the root cause analysis of the problem has been done in the light of recommendation of the CFT. There may be one or several root causes to a particular problem. Once the causes were listed down appropriate tasks were formulated to contain the problem or eliminate the problem or monitor the problem.

\begin{tabular}{|c|l|l|l|}
\hline Sl No & Nature of Problem & Specific Problem & Class of Problem \\
\hline 1 & Edge faults & Overhanging edges & Primary \\
\hline 2 & Scoring & Irregular scoring depth & Primary \\
\hline 3 & Faults in cut direction & $\begin{array}{l}\text { Cut surfaces undulating in } \\
\text { direction of cut }\end{array}$ & Tertiary \\
\hline 4 & Incomplete Cut & End not cut through & Secondary \\
\hline 5 & Adhering Slag & Slag Burrs & Tertiary \\
\hline 6 & Cracks & In the cut surface & Secondary \\
\hline
\end{tabular}

Table 3. "Types of errors in processed materials".

\subsection{Verification of logical causes and elimination of illogical causes (Step 06)}

Now, a dedicated group has been deployed to monitor the machine on a regular basis. The technique followed is termed as "Group Observation Technique (GOT)". This technique basically aims to observe any problem through relaxed attention in individual capacity and each member shall report his or her observations. It is quite different to that of a traditional inspection. The detail observations of GOT on the earlier specified problem (pivot frame and dump leaver) is tabulated in Table 4. The GOT observed that there was a dimensional error in the machined component as compared to the specified tolerance in the machine tool (obtained from the machine manual). The variation in the tabulated observed data is due to the variation of the reported data of the GOT.

\subsection{Determination of root cause (Step 07)}

To identify the root causes, Root Cause Analysis tools were used with Management Oversight and Risk Tree (MORT) methodology. The analysis and their root causes are presented in Table 5. 


\begin{tabular}{|c|c|c|c|c|}
\hline SI No & $\begin{array}{c}\text { Description of observed } \\
\text { point }\end{array}$ & $\begin{array}{c}\text { Specified } \\
\text { tolerance } \mathbf{( m m})\end{array}$ & $\begin{array}{c}\text { Actual observation } \\
\text { ( } \mathbf{m m})\end{array}$ & Remark \\
\hline 1 & $\begin{array}{c}\text { Allowable error between two } \\
\text { diagonals of a piece }\end{array}$ & 0.5 & 1.6 to 2 & 0.7 to 1.2 \\
\hline 2 & $\begin{array}{c}\text { Allowable error in Parallelism } \\
\text { between two lines }\end{array}$ & 0.2 & \pm 0.9 & \\
\hline 3 & $\begin{array}{c}\text { Allowable error in Square } \\
\text { Cut }\end{array}$ & \pm 0.5 & \pm 1 & \\
\hline 4 & $\begin{array}{c}\text { Allowable error in Edge } \\
\text { length }\end{array}$ & \pm 0.6 & \pm 1.2 & \\
\hline 5 & Allowable error of Radius cut & \pm 0.6 & & \\
\hline
\end{tabular}

Table 4. "Dimensional problems (result of group observation technique)"

\begin{tabular}{|c|c|c|c|c|c|}
\hline SI No & $\begin{array}{c}\text { Nature of } \\
\text { Problem }\end{array}$ & $\begin{array}{c}\text { Specific } \\
\text { Problem }\end{array}$ & $\begin{array}{c}\text { Class of } \\
\text { Problem }\end{array}$ & Root Cause & $\begin{array}{c}\text { Root Cause } \\
\text { Related to }\end{array}$ \\
\hline 1 & Edge faults & $\begin{array}{c}\text { Overhanging } \\
\text { edges }\end{array}$ & Primary & $\begin{array}{c}\text { Clearance between } \\
\text { Nozzle and plate } \\
\text { too high }\end{array}$ & Torch \\
\hline 2 & Scoring & $\begin{array}{c}\text { Irregular } \\
\text { scoring depth }\end{array}$ & Primary & Flame too weak & $\begin{array}{c}\text { Heating } \\
\text { Nozzle }\end{array}$ \\
\hline 3 & $\begin{array}{c}\text { Faults in cut } \\
\text { direction }\end{array}$ & $\begin{array}{c}\text { Cut surfaces } \\
\text { undulating in } \\
\text { direction of cut }\end{array}$ & Tertiary & $\begin{array}{c}\text { Cutting Oxygen } \\
\text { supply briefly } \\
\text { interrupted }\end{array}$ & $\begin{array}{c}\text { Cutting } \\
\text { Nozzle }\end{array}$ \\
\hline 4 & $\begin{array}{c}\text { Incomplete } \\
\text { Cut }\end{array}$ & $\begin{array}{c}\text { End not cut } \\
\text { through }\end{array}$ & Secondary & $\begin{array}{c}\text { Torch Speed and } \\
\text { feed too high }\end{array}$ & Torch \\
\hline 5 & Adhering Slag & Slag Burrs & Tertiary & $\begin{array}{c}\text { Cutting oxygen } \\
\text { pressure too low }\end{array}$ & $\begin{array}{c}\text { Cutting } \\
\text { Nozzle }\end{array}$ \\
\hline 6 & Cracks & In the cut \\
surface & Secondary & $\begin{array}{c}\text { Insufficient } \\
\text { preheating }\end{array}$ & $\begin{array}{c}\text { Material } \\
\text { quality }\end{array}$ \\
\hline
\end{tabular}

Table 5. "Types of errors and their root causes in processed materials".

During the root cause analysis, it was observed that the movement of the machine was not smooth. It was causing problem in the cut surface of the material. The maintenance schedule was studied and its records were compared with its recommended schedule of the manufacturer. It was a matter of surprise that the routine periodic preventive maintenance proposed by the machine supplier has not been adhered at all. The machine was installed nearly two years ago. The number of times lubrication was necessary and actually done was different. All the related data has been tabulated Table 6 .

It is evident from the Table 5 and Table 6 that there was no proper system in place and there is lack of know how of setting machine parameters. There is a complete drawback in management initiative. The tabulated results are self-explanatory. The recommended maintenance schedule is not adhered at all. In fact, the maintenance department has made its own maintenance schedule, which is contrary to the recommended schedule by the machine supplier. 


\begin{tabular}{|c|c|c|c|c|c|c|}
\hline $\begin{array}{c}\text { SI } \\
\text { No }\end{array}$ & $\begin{array}{c}\text { Lubricating } \\
\text { Point }\end{array}$ & $\begin{array}{c}\text { Frequency } \\
\text { Suggested }\end{array}$ & Duration & $\begin{array}{c}\text { Lubricant } \\
\text { Type }\end{array}$ & $\begin{array}{c}\text { Lubrication } \\
\text { Required }\end{array}$ & $\begin{array}{c}\text { Actually } \\
\text { Done }\end{array}$ \\
\hline 1 & $\begin{array}{c}\text { Sliding surface of } \\
\text { lifting shaft }\end{array}$ & 1 & 3 month & Grease & 8 & 3 \\
\hline 2 & $\begin{array}{c}\text { Lifting rack and } \\
\text { gear }\end{array}$ & 1 & 3 month & Grease & 8 & 3 \\
\hline 3 & $\begin{array}{c}\text { Engaging surface } \\
\text { of traverse rack } \\
\text { and gear }\end{array}$ & 1 & 8 Hours & $\begin{array}{c}\text { Lubricating } \\
\text { oil }\end{array}$ & $\begin{array}{c}\text { At least } 650 \\
\text { days }\end{array}$ & Irregular \\
\hline 4 & Traverse rail & 2 & 8 Hours & $\begin{array}{c}\text { Lubricating } \\
\text { oil }\end{array}$ & $\begin{array}{c}\text { At least 650 } \\
\text { times }\end{array}$ & Irregular \\
\hline 5 & $\begin{array}{c}\text { Bearing of band } \\
\text { system }\end{array}$ & 2 & 6 months & $\begin{array}{c}\text { Lubricating } \\
\text { oil }\end{array}$ & 4 & 2 \\
\hline 6 & $\begin{array}{c}\text { Engaging surface } \\
\text { of longitudinal } \\
\text { rack and gear }\end{array}$ & 2 & 8 Hours & $\begin{array}{c}\text { Lubricating } \\
\text { oil }\end{array}$ & $\begin{array}{c}\text { At least } \\
1200 \text { times }\end{array}$ & Irregular \\
\hline 7 & $\begin{array}{c}\text { Bearing for } \\
\text { longitudinal drive }\end{array}$ & 2 & 6 months & Grease & 4 & 2 \\
\hline
\end{tabular}

Table 6. "Lubrication points, their frequency and compliance".

Moreover, as revealed by the observation, most of the defects were due to problem at cutting torch. The problem was either attributable to gas condition or none cleaning of nozzle. Some more facts had come to our knowledge, regarding the setting advised by the machine supplier, while cross-examining the operators and maintenance personnel. Actually, proper settings of heating parameter and cutting parameter related to gas flow, speed of the machine, selection of proper size of nozzle etc were not set as per recommended setting of the manufacturer. This was also one of the reasons that contributed to some percentage of defects. This clearly indicated that there was a need of proper training to the employees first.

Similarly, too much overtime was given to the workers, as sufficient workers were not available. There were many other general causes, which have been presented in the cause and effect diagram (Figure 3).

\section{The Problem at cutting torch}

All kinds of cutting were done through Dissolved Acetylene and Oxygen. Gas is supplied to the machine by longitudinal hoses. The cutting quality depends on the accurate selection of gases and accurate positioning of cutting torch. The sensing mechanism maintains the distance between nozzle tip to plate, which has been recommended by the machine supplier to keep it 10 to $15 \mathrm{~mm}$. It should not be below $10 \mathrm{~mm}$. The sensing feelers must be free from the spatters or dust particles. The rack and spindle sleeve must be greased every 100 operating hours. 
It has been observed that the machine was too dirty and due to this the sensing feeler most frequently do not maintain the recommended distance as per machine specification, The lifting gear box of the single torch was to be mounted in a cast aluminium box to keep the device light. The clutch on the top of the box prevented the lifting shaft from being bent. It was interesting to note that, the mounting of the cast aluminium box was not proper. Apart from the above timely cleaning of nozzle was not a regular practice.

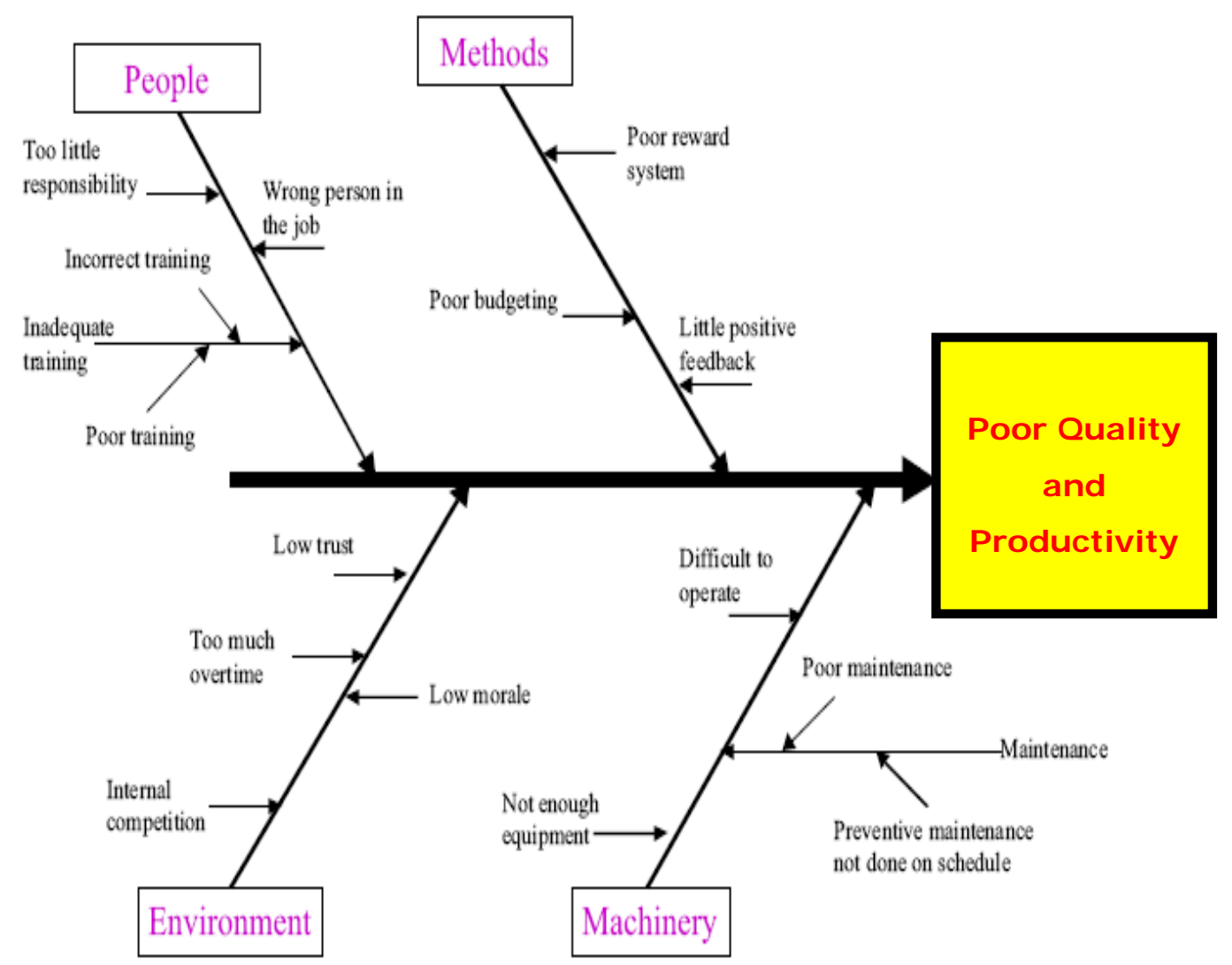

Figure 3. "Cause and effect diagram".

Thus, there have been set of interrelated activities, which were needed to be attended. The relationship has been tabulated in Table 7.

\section{Corrective and preventive actions taken after the analysis}

Training has been arranged on CNC Oxy Flame Cutting Machine, by the company for the in-charges and the operators on our recommendation. The total number of training on various accounts imparted by the organization in the fiscal year 2007- 
08 (March 2007 to September 2007) has been presented, indicating all the detail, in Figure 4.

\begin{tabular}{|c|l|l|l|l|}
\hline SI No & Why-Why Analysis & Answer & Finding and Action & Remark \\
\hline 1 & $\begin{array}{l}\text { Why Excessive chips } \\
\text { and non-uniform } \\
\text { edges occurred }\end{array}$ & $\begin{array}{l}\text { Machine has some } \\
\text { problem }\end{array}$ & $\begin{array}{l}\text { Machine is running } \\
\text { smoothly. }\end{array}$ & Observe fault \\
\hline 2 & $\begin{array}{l}\text { Why machine giving } \\
\text { faulty edges. }\end{array}$ & $\begin{array}{l}\text { Due to pressure, } \\
\text { Moisture content in } \\
\text { gases, or Movement } \\
\text { of machine / Torch }\end{array}$ & $\begin{array}{l}\text { Clean and Check } \\
\text { Nozzles size, Check } \\
\text { Moisture, and } \\
\text { operation of Torch }\end{array}$ & $\begin{array}{l}\text { Nozzles were not } \\
\text { Cleaned. X axis } \\
\text { parallel movement not } \\
\text { ok due to dirty tracks }\end{array}$ \\
\hline 3 & $\begin{array}{l}\text { Are components of a } \\
\text { torch ok }\end{array}$ & $\begin{array}{l}\text { Lifting gear box } \\
\text { Mounting was loose }\end{array}$ & $\begin{array}{l}\text { Fastening bolts and } \\
\text { nuts were not } \\
\text { present. }\end{array}$ & $\begin{array}{l}\text { When popping occurs } \\
\text { the torch setting } \\
\text { disturbs. }\end{array}$ \\
\hline 5 & $\begin{array}{l}\text { Why Fastening bolts } \\
\text { and nuts were not } \\
\text { present }\end{array}$ & $\begin{array}{l}\text { Four drill hole were } \\
\text { not matching }\end{array}$ & $\begin{array}{l}\text { Fixed in only two } \\
\text { bolts. }\end{array}$ & $\begin{array}{l}\text { Apply 5S, TPM. } \\
\text { Display fact sheet }\end{array}$ \\
\hline Why not replaced & $\begin{array}{l}\text { The part was not } \\
\text { available }\end{array}$ & $\begin{array}{l}\text { Take corrective and } \\
\text { preventive action }\end{array}$ & $\begin{array}{l}\text { Set preventive dates } \\
\text { accountability, } \\
\text { Improve MRP. }\end{array}$ \\
\hline
\end{tabular}

Table 7. "Root cause detection on the cutting torch".

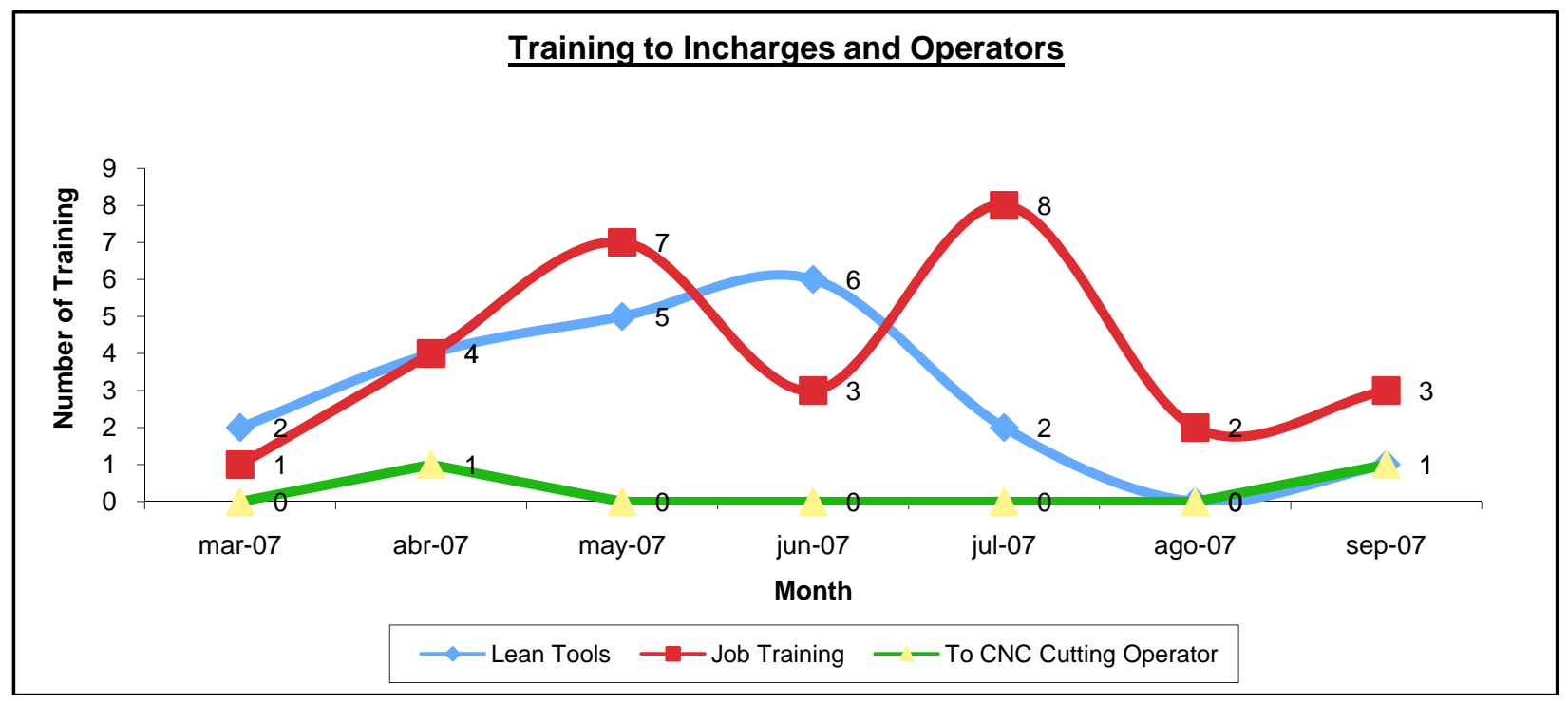

Figure 4. "Types of training to in-charges and operators".

After implementation of proper maintenance schedule and giving training to the operators and maintenance persons, data were collected to estimate the improvement in quality in terms of rejection. The trend analysis of a month for every alternate day has been plotted and presented in Figure 5. It broadly highlights as accepted or rejected. It is clear from Figure 5 that rejection has almost negligible due to attaining the skill within a very short time after the training. The comparative trend of cutting defects has been presented in Figure 6 . 


\begin{tabular}{|c|c|c|c|c|c|}
\hline SI No & $\begin{array}{l}\text { Operation in } \\
\text { Sequence }\end{array}$ & $\begin{array}{l}\text { Machine wise } \\
\text { Activity Description }\end{array}$ & $\begin{array}{l}\text { Resources } \\
\text { involved }\end{array}$ & $\begin{array}{l}\text { Time } \\
\text { taken } \\
\text { (Min) }\end{array}$ & $\begin{array}{l}\text { Category } \\
\text { (VA/ } \\
\text { NVA) }\end{array}$ \\
\hline 1 & $\begin{array}{l}\text { Raw Material } \\
\text { handling }\end{array}$ & $\begin{array}{l}\text { Handling from stock } \\
\text { yard to Cortina M/c }\end{array}$ & $\begin{array}{l}1 \text { Helper, EOT } \\
\text { Crane, } 1 \text { Operator }\end{array}$ & 15 & NVA \\
\hline 2 & Data conversion & $\begin{array}{l}\text { DNC to CNC Cortina } \\
\text { Machine }\end{array}$ & $\begin{array}{l}1 \text { Engineer, } 1 \\
\text { Computer }\end{array}$ & 10 & NVA \\
\hline 3 & CNC Cutting & At Cortina Machine & 1 Operator & 30 & VA \\
\hline 4 & $\begin{array}{l}\text { Material Removal \& } \\
\text { shifting }\end{array}$ & From Cortina Machine & 2 helper, 1 Crane & 10 & NVA \\
\hline 5 & Inspection & At cortina machine & 1 Inspector & 15 & NVA \\
\hline 6 & Assembly & $\begin{array}{l}\text { Material prepared at } \\
\text { different location are } \\
\text { gathered \& assembled }\end{array}$ & $\begin{array}{l}1 \text { Operator, } 2 \\
\text { Helper, Fixtures, } \\
\text { Gauges }\end{array}$ & 40 & VA \\
\hline 7 & $\begin{array}{l}\text { Loading \& setting at } \\
\text { Manipulator }\end{array}$ & For welding & $\begin{array}{l}\text { EOT Crane, } 1 \\
\text { Operator }\end{array}$ & 7 & NVA \\
\hline 8 & Welding & Mig welding & $\begin{array}{l}1 \text { Operator, Co2 } \\
\text { Gas, Welding } \\
\text { Machine }\end{array}$ & 50 & VA \\
\hline 9 & Inspection & UT machine & 1 Inspector & 15 & NVA \\
\hline 10 & $\begin{array}{l}\text { Unloading \& } \\
\text { Shifting to } \\
\text { Machining }\end{array}$ & Fork lift, EOT Crane & 1 Helper, Fork lift & 20 & NVA \\
\hline 11 & Setting at VTL & For machining & $\begin{array}{l}1 \text { Helper, EOT } \\
\text { Crane, } 1 \text { Operator }\end{array}$ & 20 & NVA \\
\hline 12 & Base Machining & Fixture \& special tool & 1 Operator & 45 & VA \\
\hline 13 & Inspection & Vernier, Jig & 1 Inspector & 20 & NVA \\
\hline 14 & $\begin{array}{l}\text { Unloading \& } \\
\text { Shifting to Boring }\end{array}$ & Fork lift, EOT Crane & $\begin{array}{l}1 \text { Helper, Fork lift, } \\
\text { EOT Crane }\end{array}$ & 20 & NVA \\
\hline 15 & $\begin{array}{l}\text { Setting at } \\
\text { Horizontal Boring }\end{array}$ & For machining & $\begin{array}{l}1 \text { Helper, EOT } \\
\text { Crane, } 1 \text { Operator }\end{array}$ & 20 & NVA \\
\hline 16 & Boring & $\varnothing 90 \pm 1 ., \varnothing 80 \pm 1$ & 1 Operator & 30 & VA \\
\hline 17 & $\begin{array}{l}\text { Unloading \& } \\
\text { Shifting to Drilling } \\
\text { \& Tapping }\end{array}$ & Fork lift, EOT Crane & $\begin{array}{l}1 \text { Helper, Fork lift, } \\
\text { EOT Crane }\end{array}$ & 15 & NVA \\
\hline 18 & $\begin{array}{l}\text { Setting at Radial } \\
\text { Drill }\end{array}$ & For Drilling & $\begin{array}{l}1 \text { Helper, EOT } \\
\text { Crane, } 1 \text { Operator }\end{array}$ & 20 & NVA \\
\hline 19 & Drilling \& Tapping & $\varnothing 15.5+0.2, \varnothing 20+0.3$ & 1 Operator & 60 & VA \\
\hline 20 & Inspection & Gauge, Tap & 1 Inspector & 25 & NVA \\
\hline 21 & $\begin{array}{l}\text { Unloading \& } \\
\text { Shifting to cleaning }\end{array}$ & Fork lift, EOT Crane & $\begin{array}{l}1 \text { Helper, Fork lift, } \\
\text { EOT Crane }\end{array}$ & 10 & NVA \\
\hline \multirow[t]{2}{*}{22} & $\begin{array}{l}\text { Cleaning \& surface } \\
\text { treatment }\end{array}$ & Phosphating \& Rustoil & $\begin{array}{l}1 \text { Operator, } 1 \\
\text { helper }\end{array}$ & 25 & NVA \\
\hline & Total & & & 507 & \\
\hline
\end{tabular}

Table 8. "Value stream mapping after root cause analysis" 


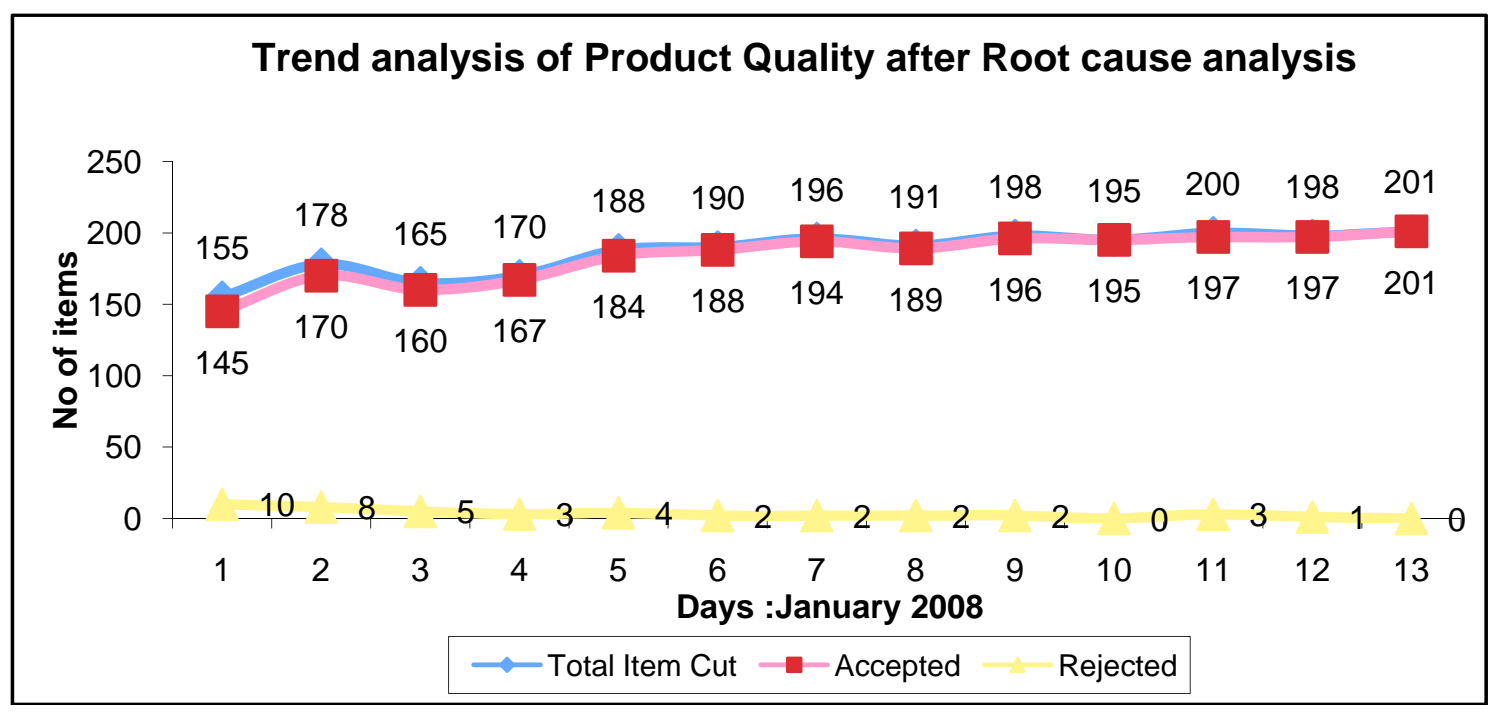

Figure 5. "Trend analysis of cutting products after root cause elimination".

The value stream mapping was done after root cause elimination, which has been shown in Table 8 and Figure 7 respectively.

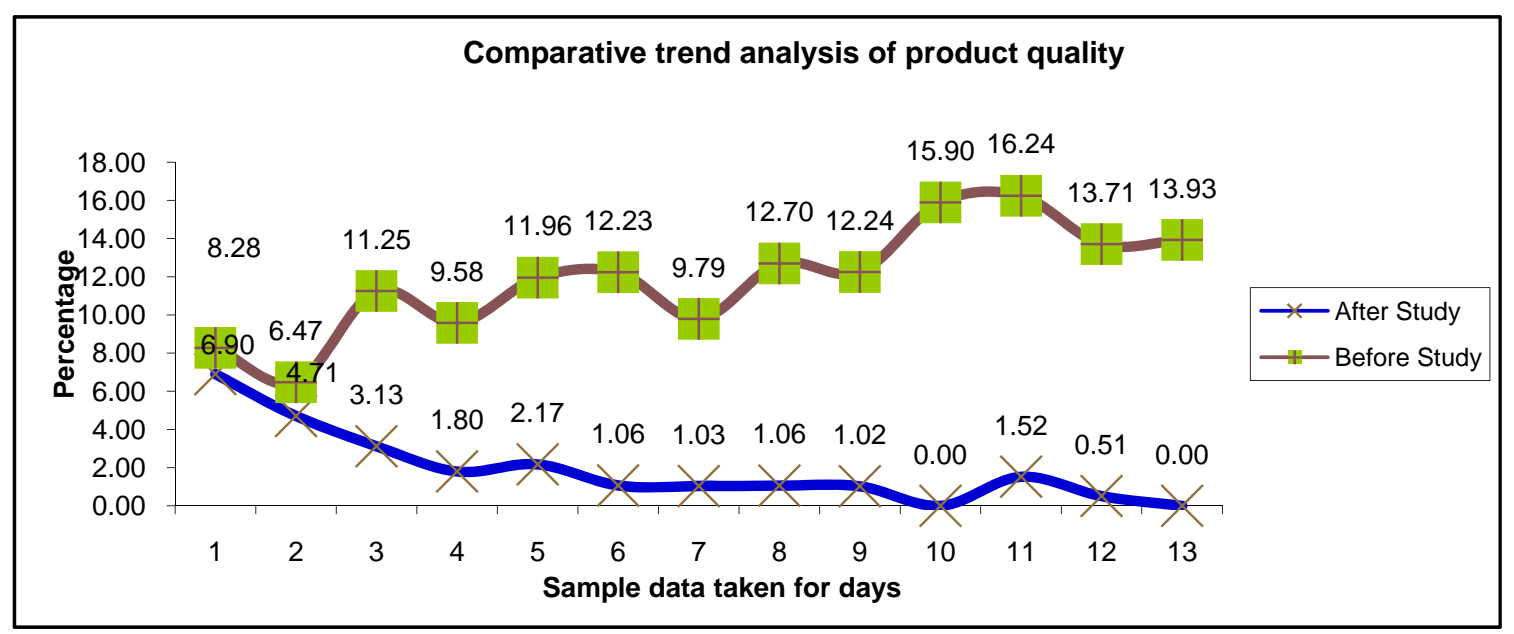

Figure 6. "Comparative trend analysis of cutting products before after Root Cause analysis". 


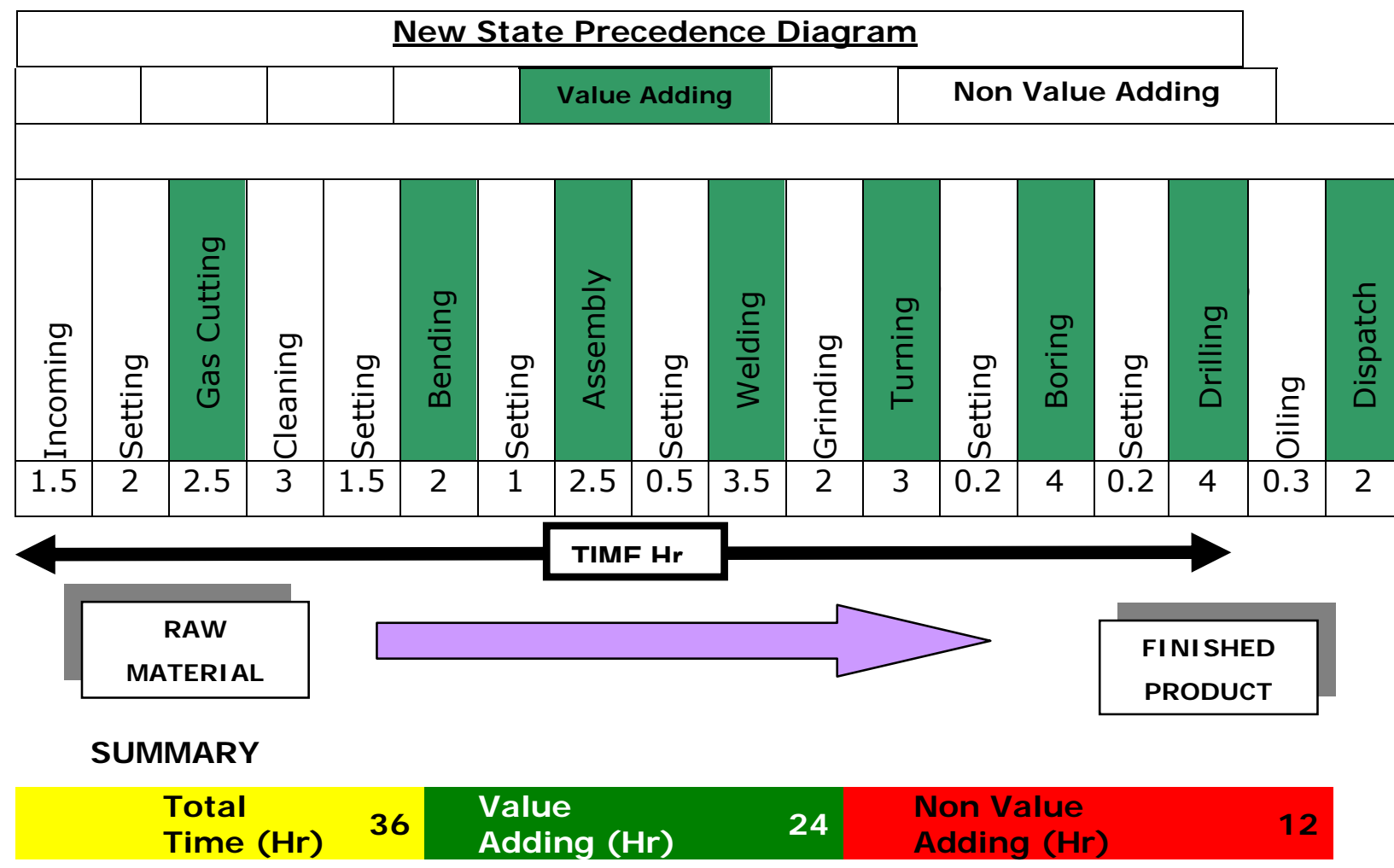

Note: In process Inspection is carried out at every stage

Figure 7. "Value Stream Mapping after root cause analysis of dump lever".

Table 9 represents the comparison of results of pivot frame before and after the root cause analysis.

\begin{tabular}{|c|c|c|c|c|c|c|}
\hline SI No & Status & \multicolumn{2}{|c|}{ Before root cause } & \multicolumn{2}{c|}{$\begin{array}{c}\text { After root cause } \\
\text { elimination }\end{array}$} & \% Change \\
\hline 1 & $\begin{array}{c}\text { Time in } \\
\text { Minutes }\end{array}$ & Total Time & $\%$ & Total Time & $\%$ & $(+$ Or -$)$ \\
\hline 2 & $\begin{array}{c}\text { Value } \\
\text { Adding }\end{array}$ & 310 & 40.25 & 260 & 51.28 & +16.13 \\
\hline 3 & $\begin{array}{c}\text { Non Value } \\
\text { Adding }\end{array}$ & 460 & 59.75 & 247 & 48.72 & -46.30 \\
\hline
\end{tabular}

Table 9. "Comparison of results of pivot frame"

\section{Comparison of torch qualities and productivity}

After implementation of root cause analysis and elimination of defects, it has been observed that the quality trend has improved a lot, but still some problems have been left, which needs to be addressed. 
In order to test the variation in quality and productivity of Oxy Flame Cutting Machine by three torches A, B and C, data has been gathered for all the shifts. Thereafter, Multi Vari Analysis approach was adopted. It is imperative here to mention that Multi Vari Analysis tries to find the relation among cyclic effects, temporal effects and positional effect.

An ANOVA test has been carried out to test the productivity contribution of each torch statistically. However, this ANOVA test may also be carried out by MINITAB 15 software.

The data has been collected for January 2008. The weekly averages of no of good pieces produced by all the cutting torches have been worked out, which has been tabulated in Table 10.

\begin{tabular}{|c|c|c|c|c|c|}
\hline Production averages & Week 1 & Week 2 & Week 3 & Week 4 & Week 5 \\
\hline Torch A & 220 & 251 & 226 & 246 & 260 \\
\hline Torch B & 244 & 235 & 232 & 242 & 225 \\
\hline Torch C & 252 & 272 & 250 & 238 & 256 \\
\hline
\end{tabular}

Table 10. "Weekly averages of production by the torches".

We have $\mathrm{m}$ independent samples, whose size is $\mathrm{n}$ and where the members of the ith sample $-X_{i 1}, X i 2, \ldots, X_{i n}$ are normal random variables with unknown mean $\mu_{i}$ and unknown variance $\sigma^{2}$, as the Equation 1 shows:

$$
X_{i j} \sim N\left(\mu_{i,} \sigma^{2}\right), \text { where, } \mathrm{i}=1 \ldots \mathrm{m} \text { and } \mathrm{j}=\ldots \mathrm{n}
$$

Equation 1. "Samples".

The hypothesis to be tested is the productivity contribution is the same in the three torches or not. Let,

- $\mathrm{HO}: \mu_{1}=\mu_{2}=\ldots \ldots \ldots \ldots=\mu_{\mathrm{m}}$

- $\mathrm{H}_{1} \neq$ equal /i.e. means are not equal.)

The algebraic identity, called the sum of squares identity, is useful in doing these types of computations. The Equation 2 shows the statistic for computing sum of square identity: 


$$
\sum_{i=1}^{m} \sum_{j=1}^{n}\left(X_{i j}\right)^{2}=n m X^{2}+S S_{b}+S S_{w}
$$

Equation 2. "Statistic for computing sum of square identity".

Where $\mathrm{SS}_{\mathrm{b}}$ and $\mathrm{SS}_{\mathrm{w}}$ are calculated as the Equation 3 and Equation 4 shows:

$$
S S_{w}=\sum_{i=1}^{m} \sum_{j=1}^{n}\left(X_{i j}-\bar{X}_{i}\right)^{2}
$$

Equation 3. "Within samples sum of squares".

$$
S S_{b}=n \sum_{i=1}^{m}\left(X_{i}-\bar{X}\right)^{2}
$$

Equation 4. "Between samples sum of squares".

The above table can be simplified by subtracting each value with 220 that subtracting a constant from each data; value will not affect the value of test statistic. Hence the new Table 10 can be formed as follows

\begin{tabular}{|c|c|c|c|c|c|c|c|}
\hline $\begin{array}{c}\text { Production } \\
\text { averages }\end{array}$ & Week 1 & Week 2 & Week 3 & Week 4 & Week 5 & $\sum_{j} X_{i j}$ & $\sum_{j} X^{2}{ }_{i j}$ \\
\hline Torch A & 0 & 31 & 6 & 26 & 40 & 103 & 3273 \\
\hline Torch B & 24 & 15 & 12 & 22 & 5 & 78 & 1454 \\
\hline Torch C & 32 & 52 & 30 & 18 & 36 & 168 & 6248 \\
\hline
\end{tabular}

Table 11. "Modified weekly averages of production by the torches".

From the Table 11 (where $m=3$ and $n=5$ ) and the Equations 1-4, we obtain a value of 2.60 in the test statistic, as Equation 5 shows:

$$
\mathrm{TS}=\frac{\frac{s s_{b}}{m-1}}{\frac{s s_{w}}{n m-m}}=\frac{\frac{863.3335}{2}}{\frac{1991.5785}{12}}=2.60
$$

Equation 4. "The value of test statistic $(m=3$ and $n=5)$ ".

\subsection{I nference from Statistical Calculation}

Now, by comparing the calculated value with tabulated value of $F .05, n, m$, we see that $F_{2.12,05}=3.89$. Hence, because the value of the test static does not exceed 
3.89 , it cannot be, at 5 percent level of significance, rejected the null hypothesis that the torches give equal production i.e. all the torches produce equal quality and productivity at 5 percent level of significance.

\section{Conclusions}

The conventional Root Cause Analysis Tools and Methods provide some structure to the process of human event problem solving. This empirical study shows as to how they can be used and how it can be communicated to others with full appreciation. How the solutions will prevent the problem from recurring. Thus, it is the only process which allows all stakeholders to have a clear idea and the reality to promote its effective solution all the time. The Root Cause Tools and Methods could be utilized according to prevalent conditions and situations of Man, Material, Machines, Systems and Processes.

In the framework of this study, the following conclusions can be drawn

- It has been observed that the percentage increase in value adding is + $20.00 \%$, whereas, percentage reduction in non-value adding is $-25.00 \%$ after implementation of root cause analysis of dump lever.

- It has been observed that the percentage increase in value adding is + $16.13 \%$, whereas, percentage reduction in non-value adding is $-46.30 \%$ after implementation of root cause analysis of pivot frame.

- The rejection has reduced from $11.87 \%$ to $1.92 \%$ on an average due to attaining the skill within a very short time after implementation of proper maintenance schedule and giving training to the operators and maintenance persons.

- It has been observed that after application of Root Cause Analysis, the product quality and productivity of the plant has improved. The plant has now fixed a very high target, from $250 \mathrm{~T}$ per month to $450 \mathrm{~T}$ per month, which may not be possible in the prevailing situation. The company will have to achieve the capacity utilization or run factor of $77 \%$ instead of earlier stated value of 55 to $65 \%$ for it. 
- All the torches A, B and C produce same level of quality and productivity at $5 \%$ level of significance.

\section{References}

Anderson, B., \& Fagerhaug, T., (2000). Root Cause Analysis: Simplified Tools and Techniques. Milwaukee: ASQ Quality Press.

Arcaro, J. S. (1997). TQM Facilitator's Guide. Boca Raton,FL: St. Lucie Press.

Brassard, M., \& Ritter, D. (1994).The Memory Jogger II: A Pocket Guide of Tools for Continuous Improvement and Effective Planning. Salem, NH: GOAL/QPC.

Brassard, M. (1996). The Memory Jogger Plus+: Featuring The Seven Management and Planning Tools. Salem, NH: Goal/QPC.

Brown, J. I. (1994). Root-Cause Analysis in Commercial Aircraft Final Assembly. Master's Abstracts International, 33(6), 1901-.

Cox, J. F. III, \& Spencer, M. S. (1998). The Constraints Management Handbook. Boca Raton, FL: St.Lucie Press.

Dean, L. G. (2007). Comparison of Common Root Cause Analysis Tools and Methods. Apollo Root Cause Analysis - A new way of Thinking, $3^{\text {rd }}$ Edition.

Dettmer, H. W. (1997). Goldratt's Theory of Constraints. Milwaukee: ASQC Press.

Dew, J. R. (1991). In Search of the Root Cause. Quality Progress, 24(3), 97-107.

DOE Guideline (1992). Root Cause Analysis Guidance Document. US Department of Energy: Washington.

Duggett, A. M. (2004). A statistical Comparison of Three Root Cause Tools. J ournal of Industrial Technology, 20(2), 1-9.

Fredendall, L. D., Patterson, J. W., Lenhartz, C., \& Mitchell, B. C. (2002). What Should Be Changed?. Quality Progress, 35(1), 50-59.

Institute of Safe Medication Practice (2005). Fluoracil Incident Root Cause Analysis: Final Draft. 
Lepore, D., Cohen, O., Deming \& Goldratt E. (1999). The Theory of Constraints and the System of Profound Knowledge. Great Barrington, MA: North River Press.

Moran, J. W., Talbot, R. P., \& Benson, R. M. (1990). A Guide to Graphical ProblemSolving Processes. Milwaukee: ASQC Quality Press.

Pasquarella, M., Mitchell, B., \& Suerken, K. (1997). A Comparison on Thinking Processes and Total Quality Management Tools. In 1997 APICS Constraints Management Proceedings: Make Common Sense: A Common Practice. Denver, CO: Falls Church, VA: APICS, 59-65.

Robson, M. (1993). Problem Solving In Groups. (2nd ed.). Brookfield, VT: Gower.

Scheinkopf, L. J. (1999). Thinking For A Change: Putting The TOC Thinking Processes to Use. Boca Raton, FL:St. Lucie Press.

Smith, D. (2000). The Measurement Nightmare: How the Theory of Constraints Can Resolve Conflicting Strategies, Policies, and Measures. Boca Raton, FL: St. Lucie Press.

Sproull, B. (2001). Process Problem Solving: A Guide for Maintenance and Operations Teams. Portland: Productivity Press.

Wilson, P. F., Dell, L. D., \& Anderson, G. F. (1993). Root Cause Analysis: A Tool for Total Quality Management. Milwaukee: ASQC Quality Press.

(c) Journal of Industrial Engineering and Management, 2008 (www.jiem.org)

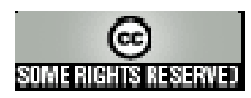

Article's contents are provided on a Attribution-Non Commercial 3.0 Creative commons license. Readers are allowed to copy, distribute and communicate article's contents, provided the author's and Journal of Industrial Engineering and Management's names are included. It must not be used for commercial purposes. To see the complete license contents, please visit http://creativecommons.org/licenses/by-nc/3.0/. 